\title{
Public Consultation: Collaboration of Government and Citizens in The Local Requirements-Based Policy Processing
}

\author{
Retno Sunu Astuti*, Asra'i Maros
}

Public Ad-ministration Departement-Social and Political Science Faculty, Universitas Diponegoro

\begin{abstract}
Public consultation is an appropriate means for engaging the public in policy-making and opening up opportunities for every citizen to have their option in following various governance processes. The collaboration of government and citizens as a form of public consultation is a process of strengthening the capacity to build sustainable cooperation among various interest groups. The benefits of collaboration are reducing conflicts of interest and improving the quality of policies. Deliberative democracy is a democratic concept which is based on a mechanism of discussion and prioritizing dialogic ways as a foundation of public consultation. Deliberative democracy allows citizens to discuss public issues and provide lessons to government to act democratically and get legitimation to important issues. DPRD as a legislative body that has the obligation to accommodate the aspirations of the community as the embodiment of public consultation implemented in the recess time. The qualitative research method used in the Bungo district case study showed that the recess period had not been fully utilized. DPRD had not been able to respond to the needs of the community so it was found that the development done in Bungo Regency is not as needed.
\end{abstract}

Keywords : public consultation, deliberative democracy, public awareness

\section{Introduction}

Power is the ability of a person or group to influence the behavior of other people or groups in accordance with the wishes of the agent. Power means the ability to influence others to think and behave in accordance with the will of influencer. In the context of the life of the nation and the state, power is defined as the authority obtained by a person or group to run the authority in accordance with the authority given. Authority means that it should not berun beyond the authority obtained [1].

After the amendment of the 1945 Constitution many changes occur both in institutional and in terms of power sharing in the Indonesian government system. The greatest changes occurred in the legislature, especially at the House of Representatives (DPR), both at the central and regional levels, namely the position of the DPR / DPRD from both the political and juridical aspects, becoming stronger to maintain the system of checks and balances in the administration. Before the amendment the power to form a law is in the hands of *Corresponding author: retnosunu2@gmail.com the President, but after the amendment of the 1945 Constitution the power to form a law is in the hands of Parliament, while the President only passed a bill that has been discussed together with the House.

Such condition depicts that the legislative body is very important in running the democratic government in Indonesia. The House of Representatives is the controlling and balancing tool to the executive power as the government wheel mover. For Indonesia that embraces the sovereignty of the people, the House of Representatives is there as a inevitability because it is unlikely to realize a government that upholds democracy without the presence of the institution. In fact, through the institution the people's interest is accommodated and poured into many kinds of policies appropriate with the people's aspiration.

The main functions of the House of Representatives (DPR) and the Local House of Representatives (DPRD) of the Provinces, Districts / Cities in Indonesia basically cover three matters, namely: the functions of legislation, the functions of budget and the functions of supervision. Before the three stages is done there are important stages that must be implemented namely the stage of accommodating 
aspiration, meaning the institution is doing a working visit to the constituent area or known as the recess. At this stage is used by each member of the board to accommodate the aspirations and listen to what the wishes and needs of the community they represent. The stage of accommodating aspirations is followed by the stages of proposal, the stage of discussion and the stage of determining the APBD. The accommodating aspirations aims to make the APBD determined by the DPRD really represents the needs of the community. The obligation of DPRD members to meet with their constituents regularly at each recess must be reported in the written form to a political party through its fraction in the DPRD. The report should contain the results of aspiration screening and the use of funds. The recess period is done 3 times a year or 14 times in a 5-year term of board member.

Article 43 Number 01 of 2015 Bungo District Rules of Procedure states that members of the BungoLocal Legislative Period 2014-2019 have obligations:

1. Absorb and collect the aspirations of constituents through regular working visits; 2. Accommodate and follow up on community aspirations and complaints 3. Give moral and political accountability to constituents in the electoral district.

The stages of accommodating the community aspiration in the recess period are in line with the concept of deliberative democracy. In the view of [2] deliberative democracy is better than other democracies, because deliberative democracies are able to produce more legitimate decisions, capable of producing better decision outcomes and capable of providing better transformation opportunities. The concept of deliberative democracy in the context of public policy is a philosophical foundation in the conduct of public consultations. Openness, participation and involvement of all elements related to the policy process provide a picture of public consultation as a deliberative process. The involvement of all elements as a form of collaboration of government and citizens into partners provides benefits in strengthening capacity to build sustainable cooperation among various interest groups [3].

\section{Methodology}

This research uses qualitative method with descriptive design which gives a detailed descriotion about certain individual or group dealing with conditions and phenomena happened [4]. Descriptive type was chosen because the researcher describes and analyzes public consultation practice executed by DPRD of Bungo Regency in accomadating people aspiration.

\section{Discussion}

In realizing deliberative democracy through the implementation of public consultations, several prerequisites are required:

1. Strong political commitment and willingness of the elite government leaders to support consistent and coherent policy implementation to be effective.

2. The willingness and ability of government stakeholders, especially the public manager to change the role from policy maker to policy moderator or policy facilitator.

3. The presence of identification and mapping of stakeholders systematically and inclusively from the beginning of the process so that the deliberation process can improve the legitimacy of the policy process, eliminate political injustice for the marginalized and improve the quality of policy output

4. Transparency that enables all stakeholders to get access to policy information which is adequately and relevant so as to increase stakeholders' knowledge, allowing stakeholders to control administrators in the use of public resources, enabling administrators to obtain a balanced supply of information and to make the policy process more accountable.

5. Need of competent facilitators, both in technical facilitation and in the substance of policy, data support, and valid and relevant information, as well as adequate participant competencies.

6. Agreeing on outputs, performance targets of measurable policy outcomes, agreeing on how to safeguard the successful policy implementation formulated together in public consultations.

7. Need of consistency of budget policies in accordance with planning policies to foster public trust.

8. Commitment from the local political elite to open the public sphere to enable a balanced process of dialogue in equality. $[5,6]$.

The recess as the embodiment of accommodating the community aspiration implemented by the Bungo District Council for the 2014-2019 Period does not fully run in accordance with the principles of public consultation as a manifestation of deliberative democracy. This can be can be seen from:

1. The quantity of accommodating the community aspiration during the recess is still low. The agenda of accommodating the community aspiration during the recess has not been routinely carried out in accordance with the Bungo Regency Bureau's Code of Conduct Number 01 of 2015 which instructed the agenda to collect the community aspiration during the recess period three times a year, and not all members of the Bungo District House of 
Representatives have collected community aspirations during the recess. This resulted in budget policy that is less in favor of the public interest.

2. The responsiveness of the District House of Representatives is still low because it has not been able to run the budget policy according to the needs of the community. This is indicated by some development programs that are less suitable to the needs of the community even seemingly still selective and there is a tendency to prioritize the interests of constituents of party supporters from the District House of Representatives members. The cases of development in the Somel Village of Tanah SepenggalLintasSubdistrict, as well as the construction of a suspension bridge in TelukPanjang Village, Bathin Sub District are some examples of the failure of the DPRD in responding to the needs of the community. This phenomenon shows that there has been clientelism. Magaloni (2006) [7] mentions clientelism as an asymmetrical and reciprocal two-way personal relationship whereby a patron gives the other material or material that the client needs to be exchanged with loyalty from the client to his patron or according to Weingrod [8] it is a mechanism when politicians provide social services or various forms of social protection to be exchanged with political support in the form of voter votes.

3. The effectiveness of the recess agenda is still low due to the lack of community participation. This is indicated by the lack of involvement of all elements of society, especially the youth element. This is in line with the results of research conducted by the National Movement for Corruption Eradication (GNPK) of Jambi Province in 2015 stating that only $9 \%$ of Bungo District people have ever been involved while $91 \%$ were never involved.

4. The quality of the recess is inadequate because the mechanism of recess implementation is not in accordance with the applicable rules. The indicator is there is no accountability reports for the results of previous recesses. The submission of accountability reports is essential so that the public knows the direction, program, and achievements of regional development that have been struggled by the members of the council.

The low quality of public consultation in Bungo District as a manifestation of deliberative democracy through recess is influenced by several factors including:

1. External environmental factor, that is socio-cultural conditions of society, especially the level of education is still low. Of the 344,100 population, those who do not pass Elementary School (SD) are $28.36 \%$, passed from SD 34.08, and only $1.6 \%$ graduated from Colleges (D3 and above. The low level of education is positively correlated with the political understanding of local people who are less supportive in the case of accommodating the community aspirations during the recess. This condition is supported by the results of research conducted by the National Movement for Corruption Eradication (GNPK) Jambi Province in 2015 , only $18 \%$ stated that they know the community aspiration during the recess, while $82 \%$ say they do not know.

2. Internal factor, that is the quality of Board members 'resources. Board members' education level is good enough. Of the 35 councilors, more than $57 \%$ are educated above senior high school, but less supported by the competence of communicating with the community. This condition affects the individual behavior of board members who are mostly lacking knowledge and experience in dealing with the community

3. Internal environment factor of organization, that is the elements of the leaders of District House. The leadership applied is less in line with the public demand. Leaders are less firmly in imposing sanctions for board members who do not carry out the accommodating of community aspiration during the recess agenda.

\section{Conclusion}

Public consultation conducted by DPRD Bungo District Period 2014-2019 in accommodating the community aspirations during the recess has not been implemented. This can be seen from the level of accountability of the recess which is still low because the act of accommodating the community aspiration has not been maximally implemented, not all community aspirations have been successfully accommodated and not all members of the local House of Bungo have implemented recess agenda. Responsiveness is still low because the local House of Bungo has not been able to respond to the needs and create the development that suits the needs of the community, this is shown by some developments in Bungo District that has not been in accordance with the needs of the community. The clientelism phenomenon is found in the planning of development programs. The effectiveness of the District HouseBungo in accommodating the community aspirations during the recess is still low because not all elements of society are involved in recess activities, especially the youth element. The quality of the recess is less effective. This can be seen from the implementation of the recess has not been yet in line with the prevailing rules, that is the absence of the accountability report on the result of previous recess by the board member. The submission of accountability reports is useful for the community to know the direction, programs, and achievements of regional development that the board members have struggled for them. 
Accommodating the community aspirations during the recess period is not running well due to several factors. External environmental factors cover local sociocultural factor; the local community low education levels resulting in the lack of the community in the implementation of the community needs, and low public awareness of the political community. In addition, the recess did not go according to regulations, as evidenced by the stalled development program. development programs are very influential with the natural environment. This proving that deliberative democracy has been achieved. The factor of internal environment of the organization also contributes in the less qualified public consultation especially the elements of leaders of the House of Representatives who are less discipline in imposing sanctions to the members of the House who do not perform reses.

Capacity building of the members of the House of Representatives in conducting public consultation is a program that must be done routinely so that public consultation requiring skill to absorb the community aspiration through recess can be utilized as a means not only to carry out the obligation as a member of the board but also to be able to realize the needs of the community in accordance with the hope of constituents. In the longterm every political party should prepare "a home of aspirations" to accommodate people's complaints without being tied to recess time.

\section{References}

1. Surbakti,Ramlan,1992.MemahamiIlmuPolitikPenuli s. 2014

2. Button, Mark and David Michael Ryfe, What We Can Learn From The Practice Of Deliberative Democracy? In Gastil, John and Peter Levine (ed), 2005, The Deliberative Democracy Handbook : Strategies For Effective Civic Engagement In The 21st Century, Jossey-Bass, San Fransisco, pp 2033,2005

3. LAN, Modul Pelatihan Analisis Kebijakan, 2017

4. Koentjaraningrat, Metode-metode Penelitian Masyarakat., 1993

5. Innes, Judith E and Booher David E, 2004, Collaborative Policy Making : Governance Through Dialogue In Hajer, Maarten and Wagenaar,Hendrik (ed), Deliberative Policy Analysis Understanding Governance in the Network Society,Cambridge University Press, UK

6. Mardiyanta, Antun, Proses Perumusan Kebijakan Perencanaan Pembangunan Daerah Dalam Perspektif Kebijakan Deliberatif (Studi Kasus di Kabupaten Probolinggo), 2013.

7. Magaloni.B, Voting For Autocracy: Hegemonic Party Survival and Its Demise in Mexico, Cambridge University Press, Cambridge, 2006

8. Sumarto, Mulyadi, Perlindungan Sosial dan Klientelisme Makna Politik Bantuan Tunai Dalam Pemilihan Umum,

9. Kansil, C.S.T danKansil, Christine, Ilmu Negara (Umumdan Indonesia), 2007. 